\title{
PENENTUAN HARI DALAM SISTEM KALENDER HIJRIAH
}

\author{
Ahmad Adib Rofiuddin \\ DPP Asosiasi Maestro Astronomi dan Ilmu Falak Indonesia Merdeka \\ (Astrofisika) Surakarta \\ e-mail: adibudin08@gmail.com
}

\begin{abstract}
Calendar is an organizing system to calculate the time for a certain period. By convention, the day is the smallest unit of the calendar, while the measurement part of a day using timing systems (hours, minutes, and seconds). Some calendar systems refers to an astronomical cycle, follow the rules anyway. The concept of day used by most people on earth is the concept of the day where the day begins at midnight and the day started on line within 1800 of the City of Greenwich. This qualitative study intends to analyze the determination of days in the Hijriyah calendar. The main problem is the disagreement about the start of the day and where the beginning of the day begins. In contrast to the international community in general, Muslims have several criteria to determine where and when the day begins in Islam. There are three opinions about the beginning of the day. First, the dawn as a benchmark of the start of the day. Second, the start of the day occurs when the setting sun. Third, the day began at midnight (00:00).

[]

Kalender merupakan sebuah sistem pengorganisasian untuk menghitung waktu selama periode tertentu. Secara konvensi, hari adalah unit kalender terkecil, sementara untuk pengukuran bagian dari sebuah hari digunakan sistem perhitungan waktu (jam, menit, dan detik). Beberapa sistem kalender mengacu kepada suatu siklus astronomi, mengikuti aturan yang tetap. Konsep hari yang dipakai oleh sebagian besar manusia di bumi adalah konsep hari dimana hari dimulai pada tengah malam dan hari dimulai di garis yang berjarak $180^{\circ}$ dari Kota Greenwich. Penelitian kualitatif ini bermaksud untuk menganalisis penentuan hari dalam kalender Hijriah. Masalah utama adalah perbedaan pendapat tentang awal hari dan di mana awal hari dimulai. Berbeda dengan masyarakat dunia pada umumnya, umat Islam mempunyai beberapa kriteria dalam menentukan dimana dan kapan hari dimulai dalam Islam. Ada tiga pendapat tentang permulaan hari. Pertama, fajar dijadikan patokan dari permulaan hari. Kedua, permulaan hari terjadi saat terbenamnya matahari. Ketiga, hari dimulai sejak tengah malam (pukul 00.00).
\end{abstract}

Keyword: hari; hilal; kalender; GMT (Greenwich Mean Time) 


\section{Pendahuluan}

Kalender merupakan suatu sistem waktu yang merefleksikan daya lenting dan kekuatan suatu peradaban. ${ }^{1}$ Kalender adalah sebuah sistem pengorganisasian untuk menghitung waktu selama periode tertentu. Secara konvensi, hari adalah unit kalender terkecil, sementara untuk pengukuran bagian dari sebuah hari digunakan sistem perhitungan waktu (jam, menit, dan detik). Beberapa sistem kalender mengacu kepada suatu siklus astronomi, mengikuti aturan yang tetap. Akan tetapi, beberapa sistem kalender ada yang mengacu pada sebuah aturan abstrak dan hanya mengikuti sebuah siklus yang berulang tanpa memiliki arti secara astronomis. Ada kalender yang dikode berdasarkan hukum tertulis, tetapi ada juga yang disampaikan melalui pesan-pesan oral. ${ }^{2}$

Sampai saat ini, diperkirakan ada sekitar 40 macam model kalender yang digunakan di muka bumi. ${ }^{3}$ Setiap sistem kalender mempunyai cara penentuan yang berbeda sesuai dengan acuan yang digunakan. ${ }^{4}$ Empat puluh macam kalender tersebut, semuanya mempunyai anomali yang dipengaruhi oleh beberapa faktor pada masing-masing kalender. ${ }^{5}$ Secara umum kalender dikategorikan ke dalam tiga mazhab besar perhitungan kalender. Pertama, kalender Masehi atau kalender Kristen yang merupakan sistem kalender yang menjadikan pergerakan matahari sebagai acuan perhitungannya (syamsiah atau solar system). Kedua, kalender bulan (kamariah) atau lunar calendar yang

1Tono Saksono, Mengkompromikan Rukyat dan Hisab (Jakarta: Amythas Publicita, 2007), h. 47.

2Makrifat Iman, Kalender Pemersatu Dunia Islam (Jakarta: Gaung Persada Press, 2010), h. v.

${ }^{3}$ S.M.T. Al-Modarresi, \& N.M. White, "Calendar Conversion for Real-time Systems", dalam: Journal of Advances in Engineering Software, Vol 35, 7 (Juli) 2004, h. 511.

${ }^{4}$ E.S. Kennedy, "Parralax Theory in Islamic Astronomy", dalam: Journal of History of Science Society Chicago Journal, Vol 47 no 1, 1956, h. 436.

5Baca: Anwar Halari, Nongnuch Tantisantiwong, David M Power, Christine Helliar, "Islamic Calendar Anomalies from Pakistani Firm-Level Data", dalam Journal of the Quaterly Review of Econmic and Finance, Januari, 2015, h. 2. Sebagai contoh adalah Kalender Maya yang mempunyai trouble setiap 0,2442 detik per hari. Lihat: Bardin, "The Amazingly Accurate Calendar System of The Maya Indians", dalam Journal of Scientific American University of Virginia, November, 1925, h. 312. Begitu juga dengan Kalender Yahudi kuno yang mengalami perubahan sesuai dengan kondisi sosial dan keagamaan. Lihat: Henry R. Huttenbach, "The Reconstrution and Evaluation of A Social Calendar As Primary Source for The History of The Jewish Community of Worms", dalam Journal of World Union of Jewish Study, Juni, 2014, h. 372. 
berdasarkan pada perjalanan bulan selama mengorbit (berevolusi terhadap bumi). Kalender Islam atau Kalender Hijriah adalah murni lunar calendar yang mengikuti siklus fase bulan tanpa ada keterkaitan dengan tahun tropis. Ketiga, luni-solar calendar, yang merupakan gabungan atas sistem lunar dan sistem solar. Kalender luni-solar memiliki urutan bulan yang mengacu pada siklus fase bulan, namun pada setiap berbagai tahun ada sebuah sisipan diberikan agar kalender ini tetap sinkron dengan kalender musim. ${ }^{6}$

Hijriah adalah jenis kalender yang dipakai oleh umat Muslim dunia. Kalender ini dibentuk berdasarkan revolusi bulan tehadap bumi. ${ }^{7}$ Karena berdasarkan peredaran bulan, maka dalam penentuan awal bulannya sering terjadi perbedaan yang disebabkan oleh ketidaksamaan antara siklus penanggalan kalender bulan dengan siklus penanggalan kalender matahari yang lazim digunakan. Masalah yang muncul adalah adanya perbedaan antara permulaan hari dan di mana permulaan hari dimulai. Berdasarkan hasil pembacaan penulis terhadap beberapa karya maupun tulisan para ulama dan ilmuwan, ditemukan beberapa perbedaan mendasar tentang permulaan hari yang menjadi penentuan permulaan awal bulan Kamariah. Melihat adanya gejolak tentang perbedaan penentuan awal hari dalam Islam, penulis bermaksud untuk melakukan kajian secara kritis terhadap permulaan hari, baik berkaitan dengan waktu maupun tempatnya.

\section{Penentuan Kapan Permulaan Hari}

Islam menjadikan peristiwa alam yang merupakan efek dari sunnatullah tentang pergerakan matahari, bumi, dan bulan sebagai acuan dalam perhitungan waktu di bumi. ${ }^{8}$ Sebagai contoh adalah firman Allah dalam surat alIsra' ayat 12:

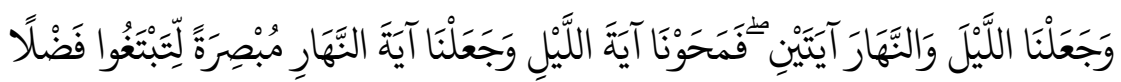

\footnotetext{
${ }^{6}$ Abdul Salam Nawawi, Ilmu Falak (Sidoarjo: Aqoba Press, 2010), h. 48.

7E.S. Kennedy, "Parralax Theory in Islamic Astronomy”, h. 34.

${ }^{8}$ Abdul Salam Nawawi, Ilmu Falak, h. 48.
} 


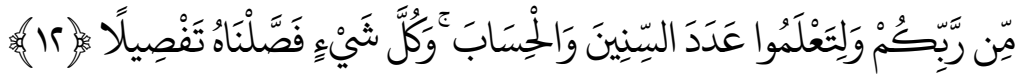

"Dan kami jadikan malam dan siang sebagai dua tanda, lalu kami hapuskan tanda malam dan kami jadikan tanda siang itu terang, agar kamu mencari kurnia dari Tuhanmu, dan supaya kamu mengetahui bilangan tahun-tahun dan perhitungan. dan segala sesuatu telah Kami terangkan dengan jelas" (Q.S. al-Isra: 12$)^{9}{ }^{9}$

Ayat ini meletakkan siang dan malam sebagai acuan dalam perhitungan tahun. Malam dan siang dikenal sebagai al-yawm (hari/tanggal), yakni periode waktu terpendek dalam takwim yang dimulai dari saat datangnya dan berakhir pada perginya siang.

Jika ingin mengetahui waktu salat, maka seseorang bisa menghitung sendiri melalui pergerakan semu matahari mengelilingi bumi. Dengan menghitung pergerakan matahari tersebut, ia dapat mengetahui waktu salat di daerahnya masing-masing. Apabila ingin mengetahui permulaan hari dalam Islam, seseorang juga tinggal mengamati fenomena alam yang terjadi ketika matahari terbenam. Begitu pula dengan permulaan awal bulan Hijriah, juga dengan melakukan pengamatan terhadap ketampakan hilal ketika matahari terbenam pada akhir bulan Hijriah.

Dalam perjalanannya, penentuan awal bulan Kamariah memiliki beberapa pendapat atau pandangan tentang kriteria pergantian bulan Kamariah. Beberapa pendapat tersebut antara lain: Pertama, pergantian bulan Kamariah itu manakala ijtima' terjadi sebelum matahari terbenam. Artinya apabila ijtima' terjadi sebelum matahari terbenam, maka malam itu dan keesokan harinya merupakan tanggal 1 bulan berikutnya. Sedangkan apabila ijtima' terjadi sesudah matahari terbenam, maka malam itu dan keesokan harinya merupakan hari ke-30 bulan yang sedang berlangsung. Kedua, bahwa pergantian bulan Kamariah itu terjadi manakala matahari terbenam lebih dahulu daripada terbenamnya bulan. Artinya, apabila matahari terbenam lebih dahulu daripada terbenamnya bulan, maka malam itu dan keesokan harinya merupakan tanggal 1 bulan berikutnya. Sedangkan apabila matahari terbenam

\footnotetext{
${ }^{9}$ Kementerian Agama RI, Al-Qur'an dan Tafsirnya (edisi yang disempurnakan) (Jakarta: Kementerian Agama RI, 2012), h. 347. 
lebih belakangan daripada terbenamnya bulan, maka malam itu dan keesokan harinya merupakan hari ke-30 bulan yang sedang berlangsung. Ketiga, bahwa pergantian bulan Kamariah itu manakala pada saat matahari terbenam, posisi hilal sudah sedemikian rupa yang menurut pengalaman hilal dapat tampak dilihat (imkān al-ru'yah) yang menurut kriteria Departemen Agama RI adalah di atas $2^{\circ}\left(>2^{\circ}\right)$ dari ufuk mar'i. Artinya, apabila pada saat matahari terbenam posisi hilal sudah imkān al-ru'yah maka malam itu dan keesokan harinya merupakan tanggal 1 bulan berikutnya dan apabila saat terbenam matahari posisi hilal belum imkān al-ru'yah, maka malam itu dan keesokan harinya merupakan hari ke-30 bulan yang sedang berlangsung. ${ }^{10}$

Memperhatikan pendapat-pendapat tersebut, maka penentuan awal bulan itu pada dasarnya adalah melakukan pengamatan terhadap waktu matahari terbenam, waktu konjungsi, serta waktu dan posisi hilal data matahari terbenam. Karena permulaan awal bulan Kamariah merupakan penentuan kapan dan di mana suatu hari itu dimulai,11 maka dalam menentukan kapan dimulainya hari terletak pada konsep visibilitas hilal (lunar crescent visibility).

Al-Qur'an menyebutkan lafal hilal hanya sekali dalam bentuk jamak, sebagaimana disebutkan surat al-Baqarah: 189:

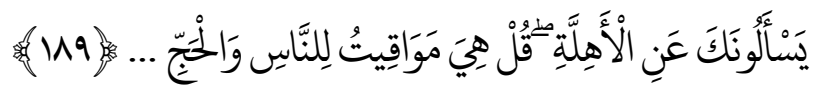

"Mereka bertanya kepadamu tentang bulan sabit. Katakanlah: "Bulan sabit itu adalah tanda-tanda waktu bagi manusia dan bagi haji ...." (QS. al-Baqarah: 189) 12

Sedangkan dalam hadis, lafal hilal banyak ditemukan. Salah satunya dalam hadis berikut:

$$
\text { حدثنا أدم حدثنا شعبة حدثنا محمد بن زياد قال سمعت أباهريرة رضي الله عنه يقول }
$$

10Muhyiddin Khazin, Ilmu Falak (Yogyakarta: Buana Pustaka Press, 2004), h. 145-146.

${ }^{11}$ Jonathan M. Golding, Joseph P. Magliano, William Bagget, "Answering When Questions about Future Events in The Context of Calendar", dalam Journal of Discourses Processes, DOI 10.1080/01638539509544941, vol 20 no 3, November, 2011, h. 266.

12Kementerian Agama RI, Al-Qur'an dan Tafsirnya, h. 212. 


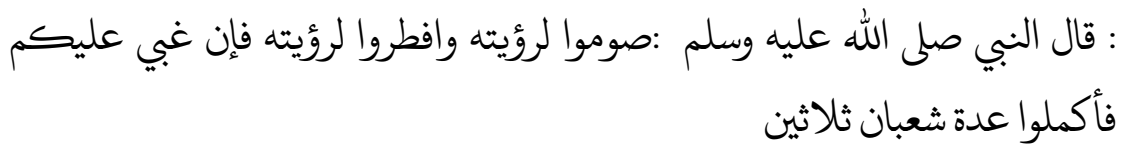

“Adam menceritakan kepada kami bahwasanya Syu'bah menceritakan kepada kami bahwasanya Muhammad bin Ziyad menceritakan kepada kami. Aku mendengar Abu Hurairah r.a berkata: Bersabda Nabi SAW: "Berpuasalah karena melihat bulan dan berbukalah karena melihat bulan. Jika ada sesuatu yang menghalangimu untuk melihat bulan, maka sempurnakanlah bilangan Sya'ban menjadi tiga puluh"13

Ayat al-Qur'an dan hadits tersebut seakan menginformasikan kepada kita bahwa hilal lah yang menjadi syarat terjadinya perubahan waktu (hari baru dan bulan baru). Hanya saja disini kriterianya tidak disampaikan mengingat pada waktu itu ilmu pengetahuan belum berkembang pesat seperti sekarang. Namun ketiadaan kriteria inilah yang akhirnya memunculkan banyak perbedaan di kalangan masyarakat Muslim dunia.

Berbagai literatur mencoba untuk memaknai kata hilal secara komprehensif. Kamus al-Munawwir setidaknya memberikan 12 makna terhadap kata hilal. Yakni: 1) Bulan sabit; 2) Bulan yang terlihat pada awal bulan; 3) Curah hujan; 4) Permulaan hujan; 5) Air sedikit; 6) Warna putih pada pangkal kuku; 7) Cap, selar pada unta; 8) Unta yang kurus; 9) Kulit kelongsong ular; 10) Debu; 11) Ular jantan; dan 12) Anak muda yang bagus. ${ }^{14}$ Adapun menurut Kamus Indonesia Inggris, kata newmoons berarti bulan baru dan crescent berarti bulan sabit.15

Ibnu Manẓūr dalam Lisān al-'Arabī menguraikan asal-usul dan makna kata hilal secara panjang lebar. Menurutnya, yang dimaksud dengan hilal adalah bulan sabit pada hari pertama dan kedua bulan Kamariah, atau dua malam terakhir bulan Kamariah. Pendapat ini didasarkan pada Abī Haytām. ${ }^{16}$ Tafsir Kementerian Agama RI menyatakan bahwa para ahli tafsir cenderung melihat

\footnotetext{
${ }^{13}$ Al-Bukhāri, Saḥịh al-Bukhāri, juz 6 (Beirut: Dār al-Kutub al-'Ilmiyyah, t.th..), h. 194.

${ }^{14}$ Ahmad Warson, Kamus al-Munawwir (Surabaya: Pustaka Progressif, 2007), h. 1616.

15M. Echols, \& Hasan Shadily, Kamus Inggris-Indonesia, Jakarta: PT Gramedia, 1986), h. 155 \& 385.

16Ibnu Manẓur, Lisān al-'Arabī, (Mesir: al-Muassasah al-Mishriyyah, t.th.), h. 227-230.
} 
pada aspek gunanya atau hikmahnya, bukan sebab hakikatnya tentang keadaan bulan secara ilmiah. ${ }^{17}$ Dalam Tafsir tersebut juga disebutkan:

"Ini bukan berarti bahwa ajaran al-Qur'an yang dibawa oleh Nabi Muhammad mengabaikan kepentingan ilmu. Malah tidak sedikit ayat al-Qur'an dan hadis yang menyuruh untuk memperkembangkan ilmu pengetahuan duniawiyah sebanyak mungkin, tapi tidak memberikan perincian, hanya memberikan petunjuk untuk mencari dan membahas sesuai dengan kemampuan, keadaan, dan perkembangan zaman sebagai umat yang diamanatkan oleh Allah untuk menjadi khalifah di muka bumi"

Muhammad Jawad Mughniyah mengatakan bahwa seluruh kaum Muslimin sepakat bahwa apabila ada yang melihat hilal seorang diri, maka ia wajib mengamalkan apa yang dilihatnya itu tanpa membedakan hilal Ramadan dengan hilal Syawal. Barangsiapa yang melihat hilal Ramadan, maka ia wajib berpuasa, sekalipun semua manusia tidak berpuasa. Barangsiapa yang melihat hilal Syawal, maka wajib berbuka walaupun semua orang di bumi masih berpuasa, tidak membedakan apakah yang melihat itu orang yang adil atau tidak, wanita atau laki-laki.19

Selanjutnya, Muhammad Jawad juga mengemukakan bahwa hampir semua mazhab menolak hisab maupun teknologi sebagai penentu dalam menetapkan awal bulan Kamariah. Namun kemudian ia berkomentar, apabila datang suatu masa di mana pengetahuan para ahli falak lebih mendetail dan komprehensif, sehingga ia seiya sekata, dan kebenaran yang telah dicapai oleh mereka telah terbukti berulang-ulang sampai pendapat mereka menjadi pasti, laksana pastinya hari-hari dalam satu minggu, seperti besok itu pasti hari Sabtu atau Ahad, maka tentu kita harus berpegang teguh pada pendapat mereka. Bahkan harus dinyatakan benar bagi orang-orang yang mencapai pengetahuan seperti pendapat mereka serta wajib menolak pendapat yang bertentangan dengan pendapat mereka. ${ }^{20}$

\footnotetext{
${ }^{17}$ Kementerian Agama RI, Al-Qur'an dan Tafsirnya, h. 339-340.

18 Ibid.

${ }^{19}$ Muhammad Jawwād Mughniyyah, al-Fiqh 'alā al-Madhāhib al-Khamsah (Beirut: Dār al-Jawwād, t.th.), h. 170 .

20Ibid., h. 173.
} 
Al-Qur'an tidak secara tegas memberikan batasan untuk menentukan permulaan hari. Al-Qur'an hanya menyampaikan dengan simbol siang hari dengan benang putih dan simbol untuk malam hari untuk benang hitam. Dari paparan tersebut, penulis mengira bahwa al-Qur'an tidak secara jelas memberikan batas antara siang dan malam. Berdasarkan hal inilah, para ulama berbeda dalam menginterpretasikan permulaan hari dalam Islam. Aliran ijtimā' qabla fajr beranggapan bahwa fajar merupakan awal dari hari dalam Islam. ${ }^{21}$ Saadoeddin Djambek berpendapat bahwa permulaan hari adalah saat terbenam matahari (waktu maghrib). Ia mengambil landasan pada firman Allah surat Yasin ayat 40.22

Kajian fiqh, menurut jumhur fuqahä', hari dimulai sejak terbenamnya matahari. Hal ini terlihat dalam hal waktu wajibnya membayar zakat fitrah (waktu tempo zakat fitrah), yaitu sejak mulainya hari Idul Fitri dalam hal ini sejak terbenamnya matahari akhir Ramadan. Oleh karena itu, orang yang meninggal sebelum terbenamnya matahari akhir Ramadan tidak dikenai kewajiban zakat fitrah. Begitu pula bayi yang lahir atau orang yang masuk Islam sesudah matahari terbenam tidak dikenai kewajiban membayar zakat fitrah, karena ia tidak lagi mengalami Ramadan yang menjadi penyebab ia wajib membayar zakat fitrah. Sebaliknya orang yang meninggal sesudah terbenamnya matahari dan bayi yang lahir atau orang masuk Islam sebelum terbenamnya matahari pada akhir Ramadan wajib membayar zakat fitrah, karena mereka mengalami Ramadan pada saat berakhirnya Ramadan dengan terbenamnya Matahari, maka zakat firtah menjadi tempo bagi mereka. ${ }^{23}$

Berbeda dengan jumhur fuqahō', para ulama Hanafi, ${ }^{24}$ sebagaimana dikutip oleh Makrifat Iman bahwa hari itu dimulai dari sejak terbit fajar,

\footnotetext{
${ }^{21}$ Sebagaimana tertuang dalam QS. al-Baqarah 187: "dan makan dan minumlah hingga terang bagimu benang putih dan benang hitam, yaitu fajar. Kemudian sempurnakanlah puasa itu sampai (datang) malam...."

22Saadoe'ddin Djambek, Hisab Awal Bulan (Jakarta: Tintamas, 1975), h. 15.

23Masykur AB dkk, Fiqih Lima Mażhab (Jakarta: Lentera, 2003), h. 197.

${ }^{24}$ Hadits diriwayatkan oleh al-Daruqutni dan Ishaq ibn Rahawaih; diriwayatkan juga oleh Abu Daud dan al-Baihaqi dengan lafal yang sedikit berbeda. Lihat: al-Dāruquțī, Sunan al- Dāruquțī, II (Beirut: Dār al-Kitāb al-'Ilmiyyah, t.t), h. 44; dan Isḥāq ibn Rahawayh, Musnad Isḥāq bin Rahawayh (Madīnah: Maktabat al-Imān, t.th), h. 429.
} 
sehingga karena itu waktu jatuh temponya (waktu wajibnya) zakat fitrah adalah sejak dimulainya hari Idul Fitri, yaitu sejak terbit fajar. Konsekuensinya, orang yang meninggal sesudah matahari terbenam pada akhir Ramadan dan sebelum fajar Idul Fitri, atau bayi yang lahir serta orang yang masuk Islam sesudah terbit fajar, semuanya tidak dikenai kewajiban zakat fitrah. Sebaliknya orang yang dikenai zakat fitrah adalah orang yang lahir atau masuk Islam masih di bulan Ramadan dan sebelum mulainya hari Idul Fitri, yakni sebelum terbit fajar pada hari itu. ${ }^{25}$ Dari pendapat tersebut, bisa disimpulkan bahwa para ulama Hanafi berpendapat bahwa hari itu dimulai saat fajar.

Berdasarkan uraian tentang pendapat dari beberapa ulama tentang permulaan hari dalam Islam, penulis cenderung mengikuti permahaman dari jumhur ulama bahwa permulaan hari dalam Islam dimulai sejak terbenamnya matahari, bukan dimulai sejak terbitnya fajar ataupun dimulai saat tengah malam. Hal ini sejalan dengan Teori Astronomical Twilight tentang perpindahan hari.

Disebutkan dalam Astronomy Encyclopedia bahwa yang dimaksud dengan twilight adalah periode senja sebelum matahari terbit dan sesudah matahari terbenam ketika pencahayaan dari langit secara bertahap. Hal ini disebabkan oleh hamburan sinar matahari oleh partikel debu dan molekul udara bumi. ${ }^{26}$ Durasi senja setelah matahari terbenam atau sebelum matahari terbit tergantung pada kondisi atmosfer (awan, debu, tekanan udara, suhu, kelembapan) dan pada sudut paralax (sudut antara jalan matahari terbenam atau terbit dan cakrawala lokal), kedua yang bervariasi dengan musim (khususnya matahari) dan garis lintang terestrial. Bromberg mengatakan panjang atau lamanya twilight umumnya lebih pendek di khatulistiwa dibanding dengan kawasan lintang yang lebih tinggi. Biasanya senja astronomi dapat berlangsung selama 1 jam di Khatulistiwa dan 1,5 jam di Kota New York. $^{27}$

25Makrifat Iman, Kalender Pemersatu Dunia Islam, h. 126.

26Leif J. Robinson, Philip's: Astronmy Encyclopedia, (London: Philip's, 2002), h. 47.

27Bromberg, (2008), h. 1. 
Menurut Ilmu Astronomi, sebagaimana yang dijelaskan oleh Rachim, dikenal istilah masa sesaat setelah matahari terbenam dan sebelum matahari terbit, yaitu twilight yang dibagi menjadi tiga tingkatan: a) Civil Twilight; b) Nautical Twilight; dan c) Astronomical Twilight. ${ }^{28}$ Berdasarkan macam-macam twilight tersebut, yang relevan dengan perpindahan hari dalam Islam adalah Astronomical Twilight, yakni jika matahari $18^{0}$ di bawah ufuk. Pada waktu itu gelap malam sudah sempurna. Astronomical Twilight berakhir ketika matahari berada $18^{0}$ di bawah cakrawala, setelah semua sinar matahari yang tersebar menghilang dari atmosfer bagian atas. Inilah yang dikatakan sebagai batas waktu shalat maghrib yang juga dimulai dengan permulaan hari dalam Islam. ${ }^{29}$

\section{Penentuan Garis Batas Hari dalam Islam}

Permasalahan penentuan dimana hari dimulai merupakan permasalahan mengenai International Date Line (IDL). ${ }^{30}$ Penggunaan kriteria ini merupakan kriteria penggunaan dalam kalender Miladiyah atau kalender Masehi. Sedangkan untuk kalender Hijriah, menggunakan kriteria International Lunar Dateline. $^{31}$

\footnotetext{
${ }^{28}$ A. Rachim, Ilmu Falak, (Yogyakarta: Liberty, 1983), h. 39.
}

${ }^{29}$ Nihayatur Rohmah, Syafaq dan Fajar, (Semarang: Program Pascasarjana IAIN Walisongo, 2012), h. 67.

30Internatoinal Date Line diibaratkan seperti sebuah piringan kecil dengan skala sudut 360 derajat. Kemudian dalam piringan tersebut pada sudut 180 derajat dibagi menjadi dua bagian (yang berwarna dan tidak). Angka 180 derajat tersebut merupakan batas penentuan hari dalam penanggalan international. Lebih lanjut: Fritz L. Kramer, "A Teaching Aid for The International Date Line", dalam Journal of Geography, DOI 10.1080/00221345208982776, 7 Januari, 2008, h. 338. Garis ini digunakan untuk menentukan di mana suatu tanggal dan hari dimulai. Garis ini terletak di Laut Pasifik pada garis bujur $180^{\circ}$. Garis ini tidak lurus mengikuti garis bujur itu dari utara ke selatan, melainkan pada tempat tertentu membelok. Belokan yang paling mencolok adalah ketika melewati Kepulauan Kiribati. Sebelum tahun 1995, kepulauan ini dibelah dua oleh garis Garis Tanggal Internasional dan pada masing-masing bagian berlaku waktu yang berbeda. Akan tetapi, pada tahun 1995 GTI ini dibelokkan ke arah timur kepulauan tersebut hingga mencapai titik ujung pada posisi $151^{\circ} \mathrm{BB}$ dan $10^{\circ} \mathrm{LS}$. Pada tahun 1884 pada International Meridian Conference, di Washington yang dihadiri perwakilan dari 25 negara, Garis Meridian Greenwich dipakai secara Internasional sebagai meridian utama yang merupakan basis perhitungan waktu GMT. Baca: W. M. Smart, Spherical Astronomy, (London: Cambridge University, 1961, (www.amazon.com) diakses pada 18 Maret 2015 pukul 01.11 WIB.

${ }^{31} \mathrm{~F}$. A. Shamsi, "Pereval's Reconstruction of The Pre-Islamic Calendar", dalam Journal Islamic Studies of Islamabad International Islamic University, vol 37, no 3, 1998, h. 364. 
Permasalahan yang terjadi para Garis Tanggal Internasional dalam sistem Miladiyah maupun Hijriah adalah menyangkut penentuan di mana hari dimulai, dipicu oleh perkembangan teknologi. Jika menengok sejarah, sebelum abad $15 \mathrm{M}$, tidak ada permasalahan tentang garis tanggal ini. Permasalahan timbul ketika manusia mengenal teknologi perkapalan, sehingga mampu mengelilingi dunia, barulah kemudian disadari perlunya menentukan garis tanggal internasional. Demikian pula dengan penanggalan Hijriah, perkembangan teknologi komunikasi membuat perbedaan penentuan garis tanggal yang sebelumnya tidak dipermasalahkan, kini menjadi masalah. ${ }^{32}$

Pergantian tanggal di suatu tempat di muka bumi berlangsung pada saat tengah malam atau jam 00 waktu setempat. ${ }^{33}$ Pemberlakuan garis batas tanggal internasional pada penanggalan di seluruh muka bumi luas daerah yang mengalami penanggalan sama selalu berubah. Keadaan ini terjadi akibat perpaduan penanggalan lokal akibat perubahan posisi Matahari dan pemberlakuan aturan garis batas internasional. Seiring berjalannya waktu, Garis Tanggal Internasional ini menyesuaikan dengan kebutuhan negaranegara pasifik (misalnya Fiji, Tuwalu, Sarnoa, dan lain-lain) yang terletak di sekitar garis ini. Selanjutnya berdasarkan garis tanggal ini dibuat zona waktu yang membagi dunia menjadi 24 bagian. Secara teoritis, setiap bagian zona waktu ini mencakup $15^{\circ}$ bujur, namun dalam kenyataan menyesuaikan dengan peta politik yang membagi dunia menjadi ratusan negara.

Sedangkan dalam penanggalan Hijriah, penentuan Garis Tanggal Kalender Islam masih bersifat dinamis, berubah pada setiap terjadi pergantian bulan. Dalam hal penentuan hari (senin, selasa, dan seterusnya) kalender Islam mengikuti garis tanggal internasional. Namun dalam penentuan tanggal, kalender Islam mengikuti garis tanggal secara dinamis yang setiap bulannya berubah-ubah. Dengan demikian karena tidak berhimpitnya garis tanggal internasional dengan garis tanggal Islam, maka akan terjadi perbedaan antara

\footnotetext{
32Khafid, "Garis Tanggal Internasional: Antara Penanggalan Miladiyah dan Hijriah", Makalah, disampaikan dalam Musyawarah Nasional Penyatuan Kalender Hijriah, yang diselenggarakan oleh Majlis Tarjih dan tajdid Muhammadiyah, Jakarta: 17-19 Desember 2005, h. 1.

33Jean Meeus, Astronomical Algorithm, (Virginia: Willman Bell, 1998), h. 57.
} 
tempat yang satu dengan tempat yang lainnya tergantung pada posisi geografisnya dalam penggunaan kalender Islam.

Mengenai garis batas tanggal Hijriah, sebenarnya merupakan garis ketinggian hilal awal bulan Hijriah. Garis ini adalah garis lengkung yang digambarkan pada peta dunia yang melewati tempat-tempat yang saat terbenam mataharinya bersamaan dengan terbenamnya bulan. Garis ini dilatarbelakangi oleh: a) Gerak matahari pada bola langit ke arah timur lebih lambat daripada gerak bulan; b) Penentuan tanggal satu bulan Hijriah didasarkan kepada penampakan hilal termuda pada saat matahari terbenam; c) Secara astronomis, saat matahari berada di horizon dapat dihitung atau diperkirakan, dan demikian pula dengan bulan untuk berbagai tempat di muka bumi; d) Melalui pendekatan dengan cara interpolasi dapat dicari tempattempat yang menunjukkan saat matahari terbenam dengan terbenamnya bulan, berdasarkan data ephemeris. ${ }^{34}$

Berbeda dengan Garis Tanggal Internasional yang selalu tetap, garis ketinggian hilal awal bulan Hijriah selalu berubah letak dan kemiringannya. Perubahan ini ditentukan oleh posisi bulan dan matahari pada waktu yang bersangkutan. ${ }^{35}$ Berdasarkan kriteria penentuan awal bulan Hijriah, di Indonesia terdapat beberapa perbedaan metode. Bagi pemakai kriteria wujud al-hilāl, ${ }^{36}$ seluruh wilayah yang mempunyai ketinggian positif sudah masuk awal bulan. Sedangkan bagi pemakai kriteria imkān al-ru'yah, ${ }^{37}$ hanya pada

${ }^{34}$ Cecep Nurwendaya, "Berlakunya Batas Tanggal Internasional Awal Bulan Qomariyah", Makalah, disampaikan dalam Musyawarah Nasional Penyatuan Kalender Hijriah, diselenggarakan oleh Badan Hisab Rukyat Departemen Agama RI, Jakarta: 17-19 Desember 2005, h. 4.

35M.S. Odeh menyatakan bahwa penentuan visibilitas hilal juga tergantung oleh kondisi atmosfer, ketajaman pengelihatan, pengalaman observer, dan lokasi pengamatan hilal. Baca: Mohammad Odeh, SH, "New Criterion for Lunar Crescent Visibility", dalam Journal of Experimental Astronomy, Vol 18, September, 2006, h. 61.

36Secara harfiah, wujūd al hilāl berarti hilal telah wujud. Sementara itu, menurut ilmu falak adalah matahari terbenam terlebih dahulu daripada bulan (meskipun hanya selisih satu menit derajat atau kurang) yang diukur dari titik Aries hingga benda langit dimaksud dengan pengukuran berlawanan dengan jarum jam. Lihat: Susiknan Azhari, Ensiklopedi Hisab Rukyat, (Yogyakarta: Pustaka Pelajar, 2008),h. 240.

${ }^{37}$ Imkān al-rukyah artinya adalah kemungkinan hilal dapat terlihat . artinya adalah batas minimal hilal dapat dirukyah. Yaitu suatu fenomena ketinggian hilal tertentu yang menurut pengalaman di lapangan hilal dapat dilihat. Dalam Astronomi dikenal dengan istilah Visibilitas Hilal Lihat: Muhyiddin Khazin, Ilmu Falak, h. 35. 
daerah berketinggian hilal $2^{0}$ atau lebih yang sudah memasuki bulan baru, yang lainnya menggenapkan bulan yang sedang berjalan. Dengan adanya kriteria ini, umat Islam (khususnya di Indonesia) dapat memprediksi daerah mana yang dapat terlihat hilal dan daerah mana yang tidak mungkin dapat terlihat hilal.

Setelah menentukan garis tanggal Hijriah yang mengacu pada penampakan hilal (visibilitas hilal), maka yang kemudian dicari adalah dimana dimulainya hari. Untuk menentukan kapan dimulainya hari, ada beberapa pendapat dari para ulama sebagai berikut:

1. Hasbi ash-Shiddieqy menyatakan bahwa hal terpenting yang harus dimufakati oleh kaum Muslimin adalah menentukan tempat yang dijadikan patokan matla',38 Hasbi menyarankan Makkah dijadikan sebagai pedoman. Alasannya, disitulah terletak Ka'bah yang menjadi kiblat dalam mengerjakan shalat. Di situ pula terletak Bayt al-Haram, Padang 'Arafah, Șafā, dan Marwā yang berperan dalam menunaikan ibadah haji. Di situ juga lah diturunkan wahyu kepada Nabi Muhammad. Tidak seorang Muslim pun membantah fungsi dan peran Makkah seperti yang disebutkan itu. Berikutnya satu hal lagi adalah kaum Muslimin seluruh dunia yang tidak sedang melakukan ibadah haji berpuasa sunnah Arafah tepat pada hari orang yang sedang berwukuf di Arafah. Selanjutnya, Hasbi mengutip hadis yang diriwayatkan oleh Zubayr ibn Muțim bahwa Nabi bersabda yang artinya "Arafah adalah tempat berkumpul (wuquf) dan hari tashrik adalah hari menyembelih kurban" Hadis ini menurut Hasbi mengandung makna bahwa hari tashrik yang tiga hari itu harus beriringan dengan hari wukuf di Arafah dan berlaku bagi seluruh umat muslim di dunia. ${ }^{39}$

2. Abū al-Fidā' (1273-1331 H), sebagaimana dikutip oleh Rudolf Wolf, menyatakan bahwa miqqāt al-qiblah berhimpit dengan garis tanggal

\footnotetext{
${ }^{38}$ Mațla' adalah tempat terbitnya benda-benda langit. Dalam bahasa Inggris disebut dengan Rising Place. Sementara itu, dalam istilah Ilmu Falak, mathla' adalah batas daerah berdasarkan jangkauan dilihatnya hilal atau dengan kata lain mathla' adalah batas geografis keberlaukan rukyat. Baca: Susiknan Azhari, Ensiklopedi Hisab Rukyat, h. 139.

${ }^{39}$ Nuruzzaman Shiddiqie, Fiqh Indonesia: Penggagas dan Gagasannya, (Yogyakarta: Pustaka Pelajar, 1997),h. 201.
} 
internasional (IDL) yang ditetapkan tahun 1886 oleh para saintis non Muslim yang telah direvisi empat kali pada tahun 1900, 1910, 1925, dan 1995. Al-Fidā' menjelaskan bahwa tergantung dari arah mana yang ditempuh, seseorang yang mengelilingi dunia akan kehilangan satu hari atau mendapatkan satu hari tambahan untuk sampai ke tempat asal. Mìqāt al-qiblah inilah yang diusulkan sebagai Islamic Date Line untuk kalender Hijriah Internasional oleh Konferensi Astronomi Islam Internasional ke-2 di Amman, Jordania, pada oktober 2001 tentang aplikasi Astronomi dalam syariat Islam. ${ }^{40}$

3. Jamaluddin Abdul Raziq, seorang ulama hisab kontemporer dari Maroko, memiliki pandangan yang sama dalam hal penentuan garis tanggal internasional. Bahwa dalam kalender Hijriah dan Kalender Miladiyah harus ada kesamaan dalam hal garis tanggal internasional, yaitu pada posisi $180^{\circ}$ (di tengah samudera pasifik) dari GMT (Greenwich Mean Time). Khalid Shaukat menyatakan sependapat dengan pemikiran Jamaluddin Abdul Raziq. Ia menyatakan bahwa alasannya mengikuti pendapat Jamaluddin Abdul Raziq adalah: Pertama, Titik acu paling logis untuk menentukan kalender Kamariah Islam global adalah Garis Tangal Internasional (International Date Line); Kedua, Apabila kelahiran bulan terjadi pada antara pukul $00.00 \mathrm{WU}$ dan pukul $12.00 \mathrm{WU}$, maka bulan baru (dalam hal ini hari baru) Islam dimulai di seluruh dunia pada hari itu sejak peristiwa terbenamnya matahari; Ketiga, Apabila kelahiran bulan terjadi antara pukul $12.00 \mathrm{WU}$ dan pukul 23.59 WU maka bulan baru (hari baru) Islam dimulai di seluruh dunia pada hari berikutnya sejak terbenamnya matahari; Keempat, Muhammad Ilyas mengusulkan apa yang ia sebut dengan Garis Tanggal Qamariyah Internasional (International Lunar Date line/ILDL). Garis tanggal usulan Ilyas ini berubah-ubah sesuai dengan perubahan visibilitas hilal pada saat visibilitas pertama yang terjadi pada setiap awal bulan..$^{41}$

${ }^{40}$ Rudolf Wolf, "Handbuch der Astronomie", dalam Journal of Ther Geschichte und Literature, Vol 1, Zurich, 1996, h. 465-466.

${ }^{41}$ Lihat: Khalid Shaukat, "Suggested Global Islamic Calendar", disampaikan dalam acara The Experts Meeting to Study The Subject of Lunar Months Calculation among Muslims, Rabat: 18 
Berdasarkan paparan dari beberapa pakar di atas, penulis lebih cenderung mengikuti pemikiran Jamaluddin Abdul Raziq. Jika penulis memaksakan mengikuti pemikiran Ilyas, maka akan semakin membingungkan bagi khalayak Muslim karena setiap hari akan terjadi perbedaan awal dimulainya hari sehingga kurang efisien dalam penggunaannya. Begitu juga jika menggunakan pendapat Hasbi as-Shiddiqiy dan Abu al-Fidā' yang menjadikan Makkah sebagai batas penanggalan Hijriah walaupun selama ini sebagian Muslim dunia mengacu kepada kalender yang berlaku di Makkah. Jika kita memaksakan mengacu kepada Makkah, konsekuensi logisnya adalah seluruh dunia harus mengacu kepada kalender yang sama dengan kalender yang selama ini dipakai di negeri ini, yakni Umm al-Qura'. Hanya saja kalender ini sering tidak konsisten, seperti yang kita ketahui bersama bahwa Arab Saudi sudah mengganti beberapa kali kriteria yang dipakai pada kalender ini. ${ }^{42}$

Desember 2006, h. 17. Lihat juga: Muhammad Ilyas, A Modern Guide to Astronomical Calculation of Islamic Calendar, Times, \& Qibla, (Kuala Lumpur: Berita Publishing Sdn. Bhd., 1984), h. 115.

${ }^{42}$ Kalender ini telah mengalami empat tahap perkembangan: (1) Fase Pertama, sejak tahun 1370 H/1950 M hingga tahun 1392 H/1972 M. Pada fase ini digunakan prinsip bahwa bulan Kamariah baru dimulai (pada keesokan hari) apabila menurut perhitungan hilalnya pada tanggal 29 bulan berjalan berada di atas ufuk pada ketinggian $9^{0}$ pada saat Matahari tenggelam (tidak ada keterangan apakah ketinggian yang dimaksud adalah ufuk Makah atau Riyad. (2) Fase Kedua, sejak tahun 1393 H/1973 M hingga tahun 1419 H/ 1998 M. Pada fase ini digunakan prinsip pembuatan kalender bahwa apabila terjadi kenjungsi pada tanggal 29 bulan berjalan sebelum pukul 00.00 GMT maka malam itu dan keesokan harinya adalah bulan baru. Prinsip ini menimbulkan masalah karena beda waktu tiga jam antara Arab Saudi dan GMT mengakibatkan bisa terjadi bahwa bulan baru di Makah sudah dimulai, padahal belum terjadi konjungsi. Misalnya konjungsi terjadi pada pukul 21.00 WU, maka di Makah pada pukul 00.00 waktu setempat dan saat itu matahari belum tenggelam. (3) Fase Ketiga, sejak tahun 1419 H/1998 M sampai pada tahun 1422 H/2002 M. Pada fase ini digunakan prinsip bulan terbenam setelah terbenam matahari (moon set after sunset) di Kota Makah, dan pada fase ini untuk pertama kalinya digunakan koordinat Ka'bah guna membuat kalender. Prinsip ini juga masih membawa kemusykilan, karena bisa saja bulan terbenam sesudah terbenamnya Matahari, namun pada saat terbenamnya Matahari belum terjadi, sehingga konjungsi belum terjadi, sehingga berakibat memasuki bulan baru pada saat belum terjadi ijtima'. Sebagai contoh adalah pada kasus bulan Rajab 1424 H (27 Agustus 2003). Konjungsi terjadi pada hari Rabu 27 Agustus 2003 pada pukul 20.26 waktu Makah. Matahari pada saat itu terbenam pukul 18.45 dan bulan terbenam 8 menit kemudian, yakni pada pukul 18.53. di sisni bulan terbenam sesudah terbenamnya Matahari, namun saat itu belum terjadi konjungsi. (4) Fase Keempat, sejak 1423 H/2003 M sampai sekarang. Pada fase ini digunakan prinsip pada sua kriteria. Pertama, pada tanggal 29 bulan berjalan telah terjadi konjungsi (meskipun baru beberapa detik) sebelum terbenamnya Matahari. Kedua, bulan terbenam sesudah terbenamnya Matahari (Bulan di atas ufuk saat Matahari terbenam). Apabila kriteria ini terpenuhi, maka malam itu dan keesokan harinya adalah bulan baru. Lihat: Zaki al-Mushtafa, dan Tasir Mahmud Hafid, Taqwim al-Umm al-Qura al-Taqwim al-Mu'tamad fi al-Mamlakah al-Arabiyyah al-Sa'udiyyah, 2001, dalam (www.icoproject.org/pdf/almosrafaHafize2001.pdf), h. 6-7. Diakses pada 
Bukan hanya itu, akan menjadi sebuah masalah baru lagi bagi daerah di sebelah Timur Makkah (khususnya dalam satu negara Arab Saudi) jika kriteria ini benar-benar diterapkan. Begitu juga dengan negara-negara yang terletak di sebelah timur Arab Saudi (Makkah).

\section{Kesimpulan}

Berdasarkan analisa yang telah dilakukan, maka penulis membuat beberapa kesimpulan sebagai berikut:

1. Berdasarkan beberapa pendapat, dikemukakan ada tiga pendapat tentang permulaan hari. Pertama, fajar dijadikan patokan dari permulaan hari; Kedua, permulaan hari terjadi saat terbenamnya matahari; Ketiga, hari dimulai sejak tengal malam (pukul 00.00). Dari ketiga pendapat tersebut, penulis cenderung menjadikan peristiwa awal dari hari dalam Islam sesuai dengan pendapat jumhur ulama.

2. Penetapan di mana dimulainya hari terdapat tiga pendapat pula. Pertama, hari dimulai dari Kota Makkah; Kedua, hari dimulai sesuai dengan peta visibilitas hilal; Ketiga, hari dimulai pada posisi $180^{\circ}$ dari GMT (yang terletak di tengah Samudera Pasifik). Dari ketiga pendapat tersebut, penulis cenderung mengikuti pendapat ketiga karena dipandang lebih efisien dan tidak menimbulkan kebingungan di tengah khalayak Muslim.

3. Kesamaan hari antar berbagai wilayah di muka bumi tidak mesti atau tidak selalu selaras dengan kesamaan tanggal. Hal ini dipengaruhi oleh ketampakan hilal dalam tempat yang bersangkutan. Jika hilal sudah berhasil dilihat, maka meskipun hari belum berganti maka tanggal dalam Hijriah sudah berganti, sebaliknya juga jika hilal belum tampak, maka meskipun hari sudah berganti maka tanggal masih tetap.[a]

15 Maret 2015 pukul 22.00 WIB. Begitu juga dengan kalender Islam di Amerika juga mengalami beberapa perubahan sesuai dengan perkembangan ilmu pengetahuan dan tekonologi pengamatan (observasi). Lihat: Na'eel Cajee, "Circular Calculus and Ecliptical Realities: The Standarization of The Islamic Lunar Calendar in The United States 1966-2006", dalam Journal of Muslim Minority Affairs, vol 31 no 3, September, 2011, h. 458. 


\section{DAFTAR PUSTAKA}

Azhari, Susiknan, Ensiklopedi Hisab Rukyat, Yogyakarta: Pustaka Pelajar, 2008.

Bardin, "The Amazingly Accurate Calendar System of The Maya Indians", dalam Journal of Scientific American University of Virginia, November, 1925.

al-Bukhari, Șahīḥ al-Bukhārī, juz 6, Beirut: Dār al-Kutub al-'Ilmiyyah, t.th.

Cajee, Na'eel, "Circular Calculus and Ecliptical Realities: The Standarization of The Islamic Lunar Calendar in The United States 1966-2006", dalam Journal of Muslim Minority Affairs, vol 31 no 3, September, 2011.

al-Dāruquṭnī, Sunan al- Dāruquțnī, II, Beirut: Dār al-Kitāb al-'Ilmiyyah, tth.

Djambek, Saadoe'ddin, Hisab Awal Bulan, Jakarta: Tintamas, 1975.

Echols, M., \& Hasan Shadily, Kamus Inggris-Indonesia, Jakarta: PT Gramedia, 1986.

Golding, Jonathan M., Joseph P. Magliano, William Bagget, "Answering When Questions about Future Events in The Context of Calendar", dalam Journal of Discourses Processes, DOI 10.1080/01638539509544941, vol 20 no 3, November, 2011.

Halari, Anwar, Nongnuch Tantisantiwong, David M Power, Christine Helliar, "Islamic Calendar Anomalies from Pakistani Firm-Level Data", dalam Journal of the Quaterly Review of Econmic and Finance, Januari, 2015, h. 2.

Huttenbach, Henry R., "The Reconstrution and Evaluation of A Social Calendar As Primary Source for The History of The Jewish Community of Worms", dalam Journal of World Union of Jewish Study, Juni, 2014.

Ibn Rahawayh, Isḥāq, Musnad Isḥāq bin Rahawayh, Madīnah: Maktabat alImān, t.th.

Ilyas, Muhammad, A Modern Guide to Astronomical Calculation of Islamic Calendar, Times, \& Qibla, Kuala Lumpur: Berita Publishing Sdn. Bhd., 1984.

Iman, Makrifat, Kalender Pemersatu Dunia Islam, Jakarta: Gaung Persada Press, 2010.

Kementerian Agama RI, Al-Qur'an dan Tafsirnya (edisi yang disempurnakan), Jakarta: Kementerian Agama RI, 2012. 
Kennedy, E.S., "Parralax Theory in Islamic Astronomy", dalam: Journal of History of Science Society Chicago Journal, Vol 47 no 1, 1956.

Khafid, "Garis Tanggal Internasional: Antara Penanggalan Miladiyah dan Hijriah", Makalah, disampaikan dalam Musyawarah Nasional Penyatuan Kalender Hijriah, yang diselenggarakan oleh Majlis Tarjih dan tajdid Muhammadiyah, Jakarta: 17-19 Desember 2005.

Khazin, Muhyiddin, Ilmu Falak, Yogyakarta: Buana Pustaka Press, 2004.

Manzur, Ibnu, Lisān al-'Arabī, Mesir: al-Muassasah al-Mishriyyah, t.th.

Masykur AB dkk, Fiqih Lima Mazhab, Jakarta: Lentera, 2003.

Meeus, Jean, Astronomical Algorithm, Virginia: Willman Bell, 1998.

al-Modarresi, S.M.T., \& N.M. White, "Calendar Conversion for Real-time Systems", dalam: Journal of Advances in Engineering Software, Vol 35, 7 (Juli) 2004.

Mughniyyah, Muhammad Jawwād, al-Fiqh 'alā al-Madhāhib al-Khamsah, Beirut: Dār al-Jawwād, t.th.

al-Mushtafa, Zaki dan Tasir Mahmud Hafid, Taqwim al-Umm al-Qura alTaqwim al-Mu'tamad fi al-Mamlakah al-'Arabiyyah al-Sa'udiyyah, 2001, dalam (www.icoproject.org/pdf/almosrafaHafize2001.pdf).

Nawawi, Abdul Salam, Ilmu Falak, Sidoarjo: Aqoba Press, 2010.

Nurwendaya, Cecep, "Berlakunya Batas Tanggal Internasional Awal Bulan Qomariyah", Makalah, disampaikan dalam Musyawarah Nasional Penyatuan Kalender Hijriah, diselenggarakan oleh Badan Hisab Rukyat Departemen Agama RI, Jakarta: 17-19 Desember 2005.

Odeh, Mohammad, SH, "New Criterion for Lunar Crescent Visibility", dalam Journal of Experimental Astronomy, Vol 18, September, 2006.

Rachim A., Ilmu Falak, Yogyakarta: Liberty, 1983.

Robinson, Leif J., Philip's: Astronomy Encyclopedia, London: Philip's, 2002.

Rohmah, Nihayatur, Syafaq dan Fajar, Semarang: Program Pascasarjana IAIN Walisongo, 2012.

Saksono, Tono, Mengkompromikan Rukyat dan Hisab, Jakarta: Amythas Publicita, 2007.

Shamsi, F. A., "Pereval's Reconstruction of The Pre-Islamic Calendar", dalam Journal Islamic Studies of Islamabad International Islamic University, Vol 37, No. 3, 1998.

Shaukat, Khalid, "Suggested Global Islamic Calendar", disampaikan dalam acara The Experts Meeting to Study The Subject of Lunar Months Calculation among Muslims, Rabat: 18 Desember 2006. 
Shiddiqie, Nuruzzaman, Fiqh Indonesia: Penggagas dan Gagasannya, Yogyakarta: Pustaka Pelajar, 1997.

Smart, W. M., Spherical Astronomy, London: Cambridge University, 1961.

Warson, Ahmad, Kamus al-Munawwir, Surabaya: Pustaka Progressif, 2007.

Wolf, Rudolf, "Handbuch der Astronomie", dalam Journal of Ther Geschichte und Literature, Vol 1, Zurich, 1996. 
136 || Volume 26, Nomor 1, April 2016 